\title{
Trierixin, a Novel Inhibitor of ER Stress-induced XBP1 Activation from Streptomyces sp.
}

\section{Structure Elucidation}

\author{
Yushi Futamura, Etsu Tashiro, Naoka Hironiwa, Jun Kohno, Maki Nishio, \\ Kazutoshi Shindo, Masaya Imoto
}

Received: July 2, 2007 / Accepted: August 20, 2007

(C) Japan Antibiotics Research Association

\begin{abstract}
Trierixin, a new member of the trieneansamycin group, has been isolated from the fermentation broth of Streptomyces sp. AC654 as an inhibitor of ER stress-induced XBP1 activation. The structure of trierixin was determined on the basis of its spectroscopical and chemical properties. Trierixin possessed a 21-membered macrocyclic lactam, which contains a methylthio-benzenediol structure, and a cyclohexanecarbonylalanine moiety. Trierixin is thus elucidated as 21-thiomethylmycotrienin II.
\end{abstract}

Keywords trierixin, triene-ansamycin, ER stress, XBP1

In the course of screening for an inhibitor of ER stressinduced XBP1 activation in HeLa cells, we isolated trierixin (1, Fig. 1), a new member of the triene-ansamycin group, from the fermentation broth of Streptomyces sp. AC654. The taxonomy of the producing strain, and the fermentation, isolation, and biological activities of 1 were reported in the preceding paper [1]. In this paper, we describe the physico-chemical properties and structure elucidation of $\mathbf{1}$.

The molecular formula of $\mathbf{1}$ was determined to be $\mathrm{C}_{37} \mathrm{H}_{52} \mathrm{~N}_{2} \mathrm{O}_{8} \mathrm{~S}$ on the basis of HRESI-MS [(M-H) ${ }^{-}$,

E. Tashiro (Corresponding author), Y. Futamura, N. Hironiwa, M. Imoto: Department of Bioscience and Informatics, Faculty of Science and Technology, Keio University, 3-14-1 Hiyoshi, Kohoku-ku, Yokohama 223-8522, Japan,

E-mail: tashiro@bio.keio.ac.jp $\mathrm{m} / \mathrm{z} 683.3372(+0.60 \mathrm{mmu})]$. The UV spectrum of $\mathbf{1}$ in $\mathrm{MeOH}$ exhibited maximum absorption at 261, 271, and $281 \mathrm{~nm}$, indicating that 1 contains a triene moiety in the molecule [2 6]. The other UV absorption at $315 \mathrm{~nm}$ shifted to longer wavelengths $(+20 \mathrm{~nm})$ by adding a drop of $1 \mathrm{M} \mathrm{NaOH}$. This characteristic shift suggested the presence of phenolic $\mathrm{OH}(\mathrm{s})$ in $\mathbf{1}$. The IR spectrum revealed that 1 possesses $\mathrm{NH} / \mathrm{OH}\left(3420 \mathrm{~cm}^{-1}\right)$, ester $\left(1740 \mathrm{~cm}^{-1}\right)$, and amide $\left(1650 \mathrm{~cm}^{-1}\right.$ and $\left.1540 \mathrm{~cm}^{-1}\right)$ functionalities. The physico-chemical properties of $\mathbf{1}$ are summarized in Table 1.

In the isolation process of $\mathbf{1}$, we also isolated and

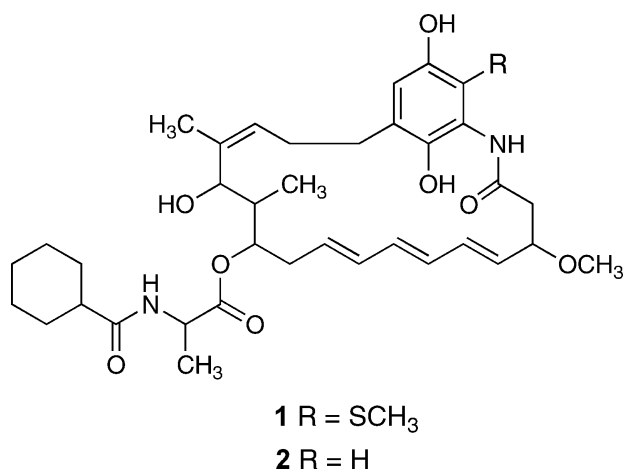

Fig. 1 Structures of trierixin (1) and mycotrienin II (2).
K. Shindo: Department of Food and Nutrition, Japan Women's University, 2-8-1, Mejirodai, Bunkyo-ku, Tokyo 112-8681, Japan

J. Kohno, M. Nishio: Discovery Research Laboratories, Tanabe Seiyaku Co., Ltd., 2-2-50, Kawagishi, Toda-shi, Saitama 3358505, Japan 
Table 1 Physico-chemical properties of trierixin (1)

\begin{tabular}{|c|c|}
\hline Appearance & pale pink powder \\
\hline Melting point $\left({ }^{\circ} \mathrm{C}\right)$ & $121 \sim 122$ \\
\hline \multicolumn{2}{|l|}{ HRESI-MS (negative) } \\
\hline found & $683.3372(\mathrm{M}-\mathrm{H})^{-}$ \\
\hline calcd & 683.3366 (for $\mathrm{C}_{37} \mathrm{H}_{51} \mathrm{~N}_{2} \mathrm{O}_{8} \mathrm{~S}$ ) \\
\hline Molecular formula & $\mathrm{C}_{37} \mathrm{H}_{52} \mathrm{~N}_{2} \mathrm{O}_{8} \mathrm{~S}$ \\
\hline Molecular weight & 684 \\
\hline$[\alpha]_{D}^{20}$ & $+306.2^{\circ}\left(\mathrm{c} 0.2, \mathrm{CHCl}_{3}\right)$ \\
\hline \multicolumn{2}{|l|}{$U \vee \lambda_{\max } \mathrm{nm}(\log \varepsilon)$} \\
\hline in $\mathrm{MeOH}$ & $\begin{array}{l}261.5(4.54), 271.0(4.66), \\
281.0(4.56), 315.0(3.65)\end{array}$ \\
\hline in $0.1 \mathrm{~N} \mathrm{HCl}-\mathrm{MeOH}$ & $\begin{array}{l}261.5(4.56), 271.0(4.67) \\
281.0(4.57), 315.0(3.67)\end{array}$ \\
\hline in $0.1 \mathrm{~N} \mathrm{NaOH}-\mathrm{MeOH}$ & $\begin{array}{l}261.5(4.43), 271.0(4.50) \\
281.0(4.40), 335.0(3.75)\end{array}$ \\
\hline $\mathrm{IR} v_{\max }(\mathrm{KBr}) \mathrm{cm}^{-1}$ & $\begin{array}{l}3420,2930,2860,1740,1650, \\
1540,1470,1380,1290,1210, \\
1160,1090,1000,960,730\end{array}$ \\
\hline HPLC Rt (minute) ${ }^{a}$ & 7.9 \\
\hline
\end{tabular}

${ }^{a}$ Column; (CAPCEL PAK C 18 ) UG120 (4.6 mm×250 mm, shiseido), $80 \%$ $\mathrm{MeOH}, 0.7 \mathrm{ml} / \mathrm{minute}$.

identified mycotrienin II (2, Fig. 1) [2, 7] as described in the preceding report [1]. Since the UV and ${ }^{1} \mathrm{H}-\mathrm{NMR}$ spectra of $\mathbf{1}$ were quite similar to those of $\mathbf{2}$, structural studies on $\mathbf{1}$ were performed by comparing with $\mathbf{2}$.

The ${ }^{1} \mathrm{H}$ - and ${ }^{13} \mathrm{C}$-NMR for $\mathbf{1}$ were assigned by analyzing ${ }^{1} \mathrm{H},{ }^{13} \mathrm{C}$, COSY, HMQC, and HMBC spectra, and compared with those for 2 (Table 2) [7]. The ${ }^{1} \mathrm{H}$ - and ${ }^{13} \mathrm{C}-\mathrm{NMR}$ spectral data for $\mathbf{1}$ are summarized in Table 2. This comparison proved that the partial structures from $\mathrm{C}-1$ to C-17 and from C-27 to C-36 (cyclohexanecarbonylalaninyl moiety) in $\mathbf{2}$ were completely preserved in $\mathbf{1}$, while one singlet methyl $\left(\delta_{\mathrm{H}} 2.17\right)$ was observed only in $\mathbf{1}$, and two aromatic methines in 2 [2] were decreased to one $\left(\delta_{\mathrm{H}} 6.78\right)$ in 1 . Considering the difference in the molecular formula between 1 and $2\left(\mathrm{CH}_{2} \mathrm{~S}\right)$, the attachment of $\mathrm{SCH}_{3}$ to $\mathrm{C}-21$ or $\mathrm{C}-23$ in $\mathbf{1}$ was thus speculated. The attachment of the $\mathrm{SCH}_{3}$ group at $\mathrm{C}-21$ was determined by the observation of ${ }^{1} \mathrm{H}-{ }^{13} \mathrm{C}$ long-range couplings from $1-\mathrm{NH}$ $\left(\delta_{\mathrm{H}} 8.53\right)$ and $\mathrm{SCH}_{3}$ to $\mathrm{C}-21\left(\delta_{\mathrm{C}} 110.9\right)$, and from $\mathrm{H}-23$ $\left(\delta_{\mathrm{H}} 6.78\right)$ to $\mathrm{C}-17\left(\delta_{\mathrm{C}} 33.2\right)$ (Fig. 2$)$. The linkage of cyclohexanecarbonylalanine at $\mathrm{C}-11$ was confirmed by the observation of a downfield shift (acylation shift) at H-11 $\left(\delta_{\mathrm{H}} 4.88\right)[8]$.

The geometries of C-4, C- 6 , and C-8 were determined to be all $E$ by the coupling constants of $J_{4,5}=15.4 \mathrm{~Hz}$, $J_{6,7}=15.0 \mathrm{~Hz}$ and $J_{8,9}=15.0 \mathrm{~Hz}$, respectively. The geometry of $\mathrm{C}-14$ was determined to be $Z$ by the ${ }^{13} \mathrm{C}$ chemical shift

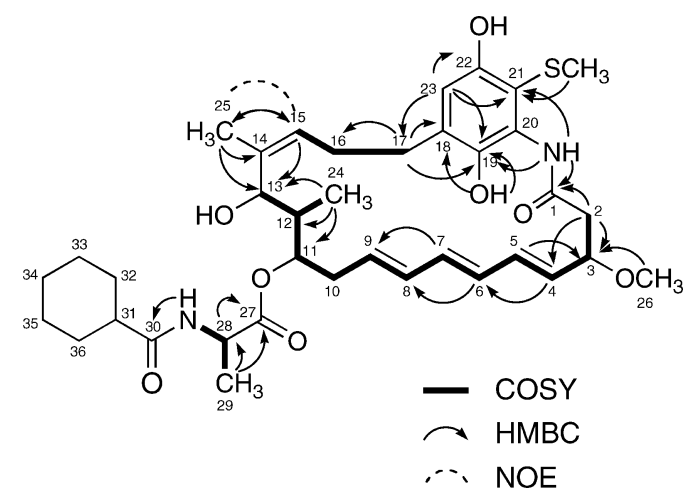

Fig. 2 Selected 2D correlations for 1.

of C-25 $\left(\delta_{\mathrm{C}} 21.2\right)$ and NOE observation between $\mathrm{H}-15$ and H-25 (Fig. 2).

From the above findings, the structure of $\mathbf{1}$ was determined as shown in Fig. 1; Trierixin (1) is 21thiomethylmycotrienin II. Studies on the relative stereochemistry are now underway.

\section{Experimental}

Melting points were determined with Yanagimoto micro melting point apparatus and are uncorrected. Mass spectra were measured with a JEOL JMS-T100LC mass spectrometer. Optical rotations were obtained on a JASCO P-1030 polarimeter using a micro-cell (light path $10 \mathrm{~cm}$ ). UV spectra and IR spectra were recorded on a Hitachi U2800 spectrophotometer and a Horiba FT-210 spectrometer in $\mathrm{KBr}$ disc, respectively. ${ }^{1} \mathrm{H}$ - and ${ }^{13} \mathrm{C}-\mathrm{NMR}$ spectra and 2D-NMR were obtained in $\mathrm{CDCl}_{3}$ on a JEOL JMN-AL-300 spectrometer using TMS as internal standard.

Acknowledgements This study was partly supported by grants from the New Energy and Industrial Technology Development Organization (NEDO) and a grant from Nateglinide Memorial Toyoshima Research and Education Fund of Keio University. Microbial extracts were obtained from The Broth Screening Network organized by Dr. H. Osada (RIKEN).

\section{References}

1. Tashiro E, Hironiwa N, Kitagawa M, Suzuki S, Nishio M, Imoto M. Trierixin, a novel inhibitor of ER stress-induced XBP1 Activation from Streptomyces sp. I. Taxonomy, fermentation, isolation, and biological activities. J Antibiot 60: 547-553 (2007)

2. Sugita M, Sasaki T, Furihata K, Seto H, Otake N. Studies on mycotrienin antibiotics, a novel class of ansamycins. II. 
Table $2 \quad{ }^{1} \mathrm{H}$ - and ${ }^{13} \mathrm{C}-\mathrm{NMR}$ data for trierixin (1) and mycotrienin II (2)

\begin{tabular}{|c|c|c|c|c|}
\hline \multirow{2}{*}{ No. } & \multicolumn{2}{|r|}{1} & \multirow{2}{*}{ No. } & \multirow{2}{*}{$\begin{array}{c}\mathbf{2} \\
\delta_{\mathrm{C}} \text { ppm } \\
\text { (multiplicity) }\end{array}$} \\
\hline & $\begin{array}{c}\delta_{\mathrm{C}} \mathrm{ppm} \\
\text { (multiplicity) }\end{array}$ & $\begin{array}{c}\delta_{\mathrm{H}} \mathrm{ppm} \\
\text { (multiplicity, } J \text { in } \mathrm{Hz} \text { ) }\end{array}$ & & \\
\hline 1 & 170.8 (s) & & 1 & $169.7(\mathrm{~s})$ \\
\hline \multirow[t]{2}{*}{2} & $43.5(t)$ & $2.66(1 \mathrm{H}, \mathrm{dd}, 8.6,13.6)$ & 2 & $43.1(\mathrm{t})$ \\
\hline & - & $2.97(1 \mathrm{H}, \mathrm{dd}, 4.5,13.7)$ & & - \\
\hline 3 & 80.0 (d) & $4.23(1 \mathrm{H}, \mathrm{m})$ & 3 & $79.6(d)$ \\
\hline 4 & $129.8(d)$ & $5.50(1 \mathrm{H}, \mathrm{dd}, 7.3,15.4)$ & 4 & $129.1(d)$ \\
\hline 5 & $135.8(d)$ & $6.28(1 \mathrm{H}, \mathrm{dd}, 10.4,15.4)$ & 5 & $134.4(d)$ \\
\hline 6 & $130.3(d)$ & $6.04(1 \mathrm{H}, \mathrm{dd}, 10.4,15.0)$ & 6 & $129.5(d)$ \\
\hline 7 & $135.5(d)$ & $6.23(1 \mathrm{H}, \mathrm{dd}, 10.4,15.0)$ & 7 & $134.9(d)$ \\
\hline 8 & 134.7 (d) & $6.04(1 \mathrm{H}, \mathrm{dd}, 10.4,15.0)$ & 8 & $133.9(d)$ \\
\hline 9 & $130.4(d)$ & $5.63(1 \mathrm{H}, \mathrm{m})$ & 9 & $129.6(d)$ \\
\hline 10 & $34.9(t)$ & $2.31,2.48(2 \mathrm{H}, \mathrm{m})$ & 10 & $33.7(t)$ \\
\hline 11 & 76.3 (d) & $4.88(1 \mathrm{H}, \mathrm{m})$ & 11 & 75.8 (d) \\
\hline 12 & 39.8 (d) & $1.85(1 \mathrm{H}, \mathrm{m})$ & 12 & 39.0 (d) \\
\hline 13 & $69.4(d)$ & $4.64(1 \mathrm{H}, \mathrm{m})$ & 13 & $68.7(d)$ \\
\hline 14 & 139.0 (s) & & 14 & $137.8(\mathrm{~s})$ \\
\hline 15 & $124.8(d)$ & $5.11(1 \mathrm{H}, \mathrm{d}, 8.8)$ & 15 & $124.3(d)$ \\
\hline 16 & $27.1(t)$ & $2.02,2.39(2 \mathrm{H}, \mathrm{m})$ & 16 & $26.6(t)$ \\
\hline 17 & $33.2(t)$ & $2.17,3.07(2 \mathrm{H}, \mathrm{m})$ & 17 & $31.7(\mathrm{t})$ \\
\hline 18 & 136.9 (s) & & 18 & $132.7(\mathrm{~s})$ \\
\hline 19 & 143.5 (s) & & 19 & $141.1(\mathrm{~s})$ \\
\hline 20 & 127.1 (s) & & 20 & $125.5(\mathrm{~s})$ \\
\hline 21 & 110.9 (s) & & 21 & $107.5(d)$ \\
\hline 22 & 150.9 (s) & & 22 & 149.2 (s) \\
\hline 23 & 116.1 (d) & $6.78(1 \mathrm{H}, \mathrm{s})$ & 23 & $115.8(d)$ \\
\hline 24 & 10.5 (q) & $0.79(3 \mathrm{H}, \mathrm{d}, 6.8)$ & 24 & $9.6(q)$ \\
\hline 25 & $21.2(q)$ & $1.70(3 \mathrm{H}, \mathrm{s})$ & 25 & $20.3(q)$ \\
\hline 26 & $57.6(q)$ & $3.36(3 \mathrm{H}, \mathrm{s})$ & 26 & $56.6(q)$ \\
\hline 27 & 174.1 (s) & & 27 & $173.3(\mathrm{~s})$ \\
\hline 28 & $49.5(d)$ & $4.43(1 \mathrm{H}, \mathrm{m})$ & 28 & 48.7 (d) \\
\hline 29 & 18.8 (q) & $1.42(3 \mathrm{H}, \mathrm{d}, 7.1)$ & 29 & $17.7(q)$ \\
\hline 30 & 177.4 (s) & & 30 & 176.9 (s) \\
\hline 31 & $46.0(\mathrm{~d})$ & $2.10(1 \mathrm{H}, \mathrm{m})$ & 31 & 45.1 (d) \\
\hline 32 & $30.4(t)$ & $1.23,1.85(2 \mathrm{H}, \mathrm{m})$ & 32 & $29.4(t)$ \\
\hline 33 & $26.6(t)$ & & 33 & $25.6(t)$ \\
\hline 34 & $26.6(t)$ & & 34 & $25.6(t)$ \\
\hline 35 & $26.7(t)$ & $1.23 \sim 1.75(6 \mathrm{H}, \mathrm{m})$ & 35 & $25.7(t)$ \\
\hline 36 & $30.5(t)$ & $1.23,1.85(2 \mathrm{H}, \mathrm{m})$ & 36 & $29.4(t)$ \\
\hline $1-\mathrm{NH}$ & & $8.53(1 \mathrm{H}, \mathrm{s})$ & & \\
\hline $19-\mathrm{OH}$ & & $7.68(1 \mathrm{H}, \mathrm{s})$ & & \\
\hline $21-\mathrm{SCH}_{3}$ & $19.4(q)$ & $2.17(3 \mathrm{H}, \mathrm{s})$ & & \\
\hline 29-NH & & $5.94(1 \mathrm{H}, \mathrm{d}, 6.6)$ & & \\
\hline
\end{tabular}

Recorded at $300 \mathrm{MHz}$ for ${ }^{1} \mathrm{H}$ and $75 \mathrm{MHz}$ for ${ }^{13} \mathrm{C}$ in $\mathrm{CDCl}_{3}$. 
Structure elucidation and biosynthesis of mycotrienins I and II. J Antibiot 35: 1467-1473 (1982)

3. Sugita M, Natori Y, Sueda N, Furihata K, Seto H, Otake N. Studies on mycotrienin antibiotics, a novel class of ansamycins. III. The isolation, characterization and structures of mycotrienols I and II. J Antibiot 35: 1474-1479 (1982)

4. Funayama S, Okada K, Komiyama K, Umezawa I. Structure of trienomycin A, a novel cytocidal ansamycin antibiotic. J Antibiot 38: 1107-1109 (1985)

5. Hosokawa N, Naganawa H, Inuma H, Hamada M, Takeuchi T, Kanbe T, Hori M. Thiazinotrienomycins, new ansamycin group antibiotics. J Antibiot 48: 471-478 (1995)
6. Nishio M, Kohno J, Sakurai M, Suzuki SI, Okada N, Kawano K, Komatsubara S. TMC-135A and B, new trieneansamycins, produced by Streptomyces sp. J Antibiot 53: 724-727 (2000)

7. Sugita M, Natori Y, Sasaki T, Furihata K, Shimazu A, Seto $\mathrm{H}$, Otake N. Studies on mycotrienin antibiotics, a novel class of ansamycins. I. Taxonomy, fermentation, isolation and properties of mycotrienins I and II. J Antibiot 35: 1460-1466 (1982)

8. Kim WG, Song NK, Yoo ID. Trienomycin G, a new inhibitor of nitric oxide production in microglia cells, from Streptomyces sp. 91614. J Antibiot 55: 204-207 (2002) 